\title{
Evaluasi Kegiatan Gowes Van Jogja sebagai Upaya Promosi Kampung Wisata Kota Yogyakarta
}

\author{
Kristian Oentoro $^{1}$, Wiyatiningsih ${ }^{2}$ \\ ${ }^{1}$ Program Studi Desain Produk, Fakultas Arsitektur dan Desain, Universitas Kristen Duta Wacana \\ Jl. Dr. Wahidin Sudirohusodo No.5-25, Kota Yogyakarta, 55224 \\ ${ }^{1} \mathrm{kristianestaff.ukdw.ac.id}$ \\ ${ }^{2}$ Program Magister Arsitektur, Fakultas Arsitektur dan Desain, Universitas Kristen Duta Wacana \\ Jl. Dr. Wahidin Sudirohusodo No.5-25, Kota Yogyakarta, 55224 \\ ${ }^{2}$ wiyatiningsihestaff.ukdw.ac.id
}

\begin{abstract}
Abstrak-Bersepeda (gowes) menjadi salah satu pendekatan untuk memulihkan kembali aktivitas pariwisata di era new normal. Selain berolahraga, kegiatan bersepeda juga menjadi kesempatan bagi pesepeda untuk rekreasi, serta mengenal berbagai objek daya tarik wisata yang dilalui. 'Gowes Van Jogja' yang diinisiasi oleh Dinas Pariwisata Kota Yogyakarta berkolaborasi dengan asosiasi industri pariwisata dalam rangkaian Jogjavaganza 2021 merupakan program promosi pariwisata yang bertujuan untuk memperkenalkan berbagai daya tarik wisata, khususnya kampung wisata melalui aktivitas bersepeda. Gowes Van Jogja pada tahun 2021 juga merupakan kegiatan perdana, sekaligus kesempatan untuk uji coba 4 dari 5 rute sepeda yang dikembangkan oleh Pemerintah Kota Yogyakarta. Evaluasi ini menggunakan metode survey secara daring (online) dengan skala likert, serta metode wawancara dengan responden yang merupakan wisatawan nusantara pada kegiatan Gowes Van Jogja 2021. Selanjutnya, hasil survey didiskusikan bersama perwakilan pengelola kampung wisata dan para pemangku kepentingan (stakeholders) yang difasilitasi oleh Dinas Pariwisata Kota Yogyakarta. Hasil survey evaluasi menunjukan indeks kepuasan peserta sebesar 80,9 yang dapat dikategorikan 'sangat baik'. Sementara itu, layanan kampung wisata, rute sepeda, suasana kampung, kerajinan, dan kuliner menjadi lima aspek evaluasi dengan penilaian 'sangat baik'. Terdapat tiga rekomendasi yang dihasilkan sebagai luaran program ini, antara lain: pengembangan program promosi Gowes Van Jogja, pemaketan layanan kampung wisata, dan pengembangan rute sepeda beserta materi pendukung promosi. Pemaketan layanan kampung wisata dengan aktivitas bersepeda diharapkan dapat mengakomodir kuliner lokal, bahkan kegiatan pelatihan untuk semakin meningkatkan kualitas layanan wisata. Inovasi layanan kampung wisata Kota Yogyakarta yang berorientasi pada kenyamanan pesepeda akan menjadi upaya promosi yang menarik di era new normal.
\end{abstract}

Kata kunci-Gowes Van Jogja, Kampung Wisata, Kota Yogyakarta, New Normal.

Abstract-Cycling (gowes) is one of the approaches to restore tourism activities in the new normal era. Besides as a sport, cycling gives the opportunity for cyclists to do recreation and to know various tourist attractions along the routes. 'Gowes Van Jogja', initiated by the Yogyakarta City Tourism Office in collaboration with tourism industry associations in the 2021 Jogjavaganza series, is a tourism promotion program that introduces various tourist attractions, especially tourist kampungs, through cycling activities. Gowes Van Jogja in 2021 is also the first activity and an opportunity to try out four of the five bicycle routes developed by the Yogyakarta City Government. This evaluation uses an online survey method with a Likert scale and an interview method with respondents who are domestic tourists at the 2021 Gowes Van Jogja activity. Furthermore, the survey results are discussed with tourism kampung managers and stakeholders facilitated by Yogyakarta City Tourism Office. The evaluation survey results show a participant satisfaction index of 80.9, which could be categorized as very good. Meanwhile, tourism kampung services, bicycle routes, kampung atmosphere, crafts, and culinary are the five aspects of the evaluation with a rating of very good. There are three recommendations produced as the output of this program, among others: the development of the Gowes Van Jogja promotion program, the packaging of tourism kampung services, the development of bicycle routes, and supporting promotional materials. The packaging of tourism kampung services with cycling activities is expected to accommodate local culinary delights and even training activities to improve tourism services' quality further. The innovation of the tourism kampung service of Yogyakarta City that aims to the cyclists comfortness will be an attractive effort for tourism in the new normal era.

Keywords - Gowes Van Jogja, New Normal, Tourism Kampong, Yogyakarta City 


\section{Pendahuluan}

Kondisi pandemi COVID-19 terjadi sejak awal tahun 2020 mendorong masyarakat untuk semakin menerapkan gaya hidup sehat dan menjaga kebugaran tubuh dengan cara berolahraga. Salah satu kegiatan olah raga atau aktivitas fisik di luar ruangan (outdoor activity) yang banyak diminati oleh masyarakat adalah bersepeda. Fenomena bersepeda di era new normal saat ini terjadi di berbagai wilayah di Indonesia, termasuk di Kota Yogyakarta. Kegiatan bersepeda di era new normal juga banyak dilakukan oleh keluarga untuk mengurangi rasa jenuh setelah lama tidak beraktivitas di luar rumah [1]. Selain memiliki tujuan untuk berolahraga, kegiatan bersepeda dapat menjadi bentuk hiburan, rekreasi, bahkan kesempatan untuk bersilaturahmi bersama kerabat dan saudara. Di Kota Yogyakarta, bersepeda juga dapat kembali menjadi gaya hidup dalam moda transportasi darat yang ramah lingkungan dan relatif mudah diakses. Pemerintah daerah dan masyarakat Kota Yogyakarta sejak tahun 2008 juga memiliki gerakan bersepeda yang dikenal dengan 'Sego Segawe' (Sepeda Kanggo Sekolah lan Nyambut Gawe) [2]. Bersepeda sebagai gerakan masyarakat Kota Yogyakarta juga menjadi daya tarik dan potensi untuk membangun kembali citra (branding) sebagai kota sepeda.

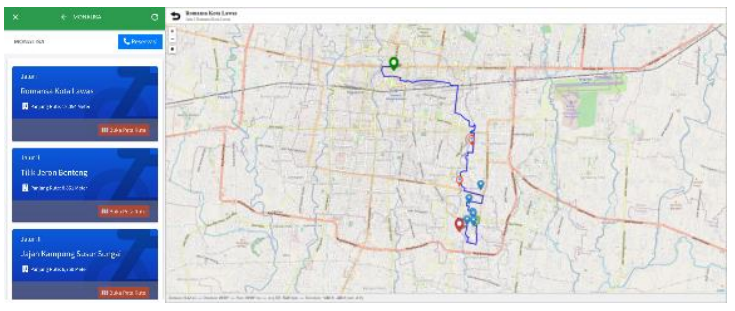

Gambar 1. Salah satu peta rute sepeda pada gowes.jogjakota.go.id Sumber Gambar : aplikasi JSS dan gowes.jogjakota.go.id

Wisata sepeda sebagai bentuk inovasi wisata olah raga (sport tourism) juga merupakan salah satu pintu masuk (entry point) dalam memulihkan aktivitas sosial-ekonomi di sektor pariwisata Kota Yogyakarta. Bersepeda dalam kegiatan pariwisata atau dikenal dengan wisata bersepeda (cycling tourism) mampu mendukung konsep pariwisata yang berkelanjutan dan ramah lingkungan [3]. Melihat berbagai potensi dalam wisata bersepeda di era new normal, muncul inisiasi dan dorongan dari Pemerintah Kota Yogyakarta untuk memperkenalkan konsep wisata bersepeda dalam rangka memperkenalkan potensi pariwisata, terutama di kampung-kampung wisata Kota Yogyakarta. Oleh karena itu, Pemerintah Kota Yogyakarta mengembangkan 5 rute sepeda pada pertengah tahun 2020 melalui aplikasi Jogja Smart Service (JSS) dan website gowes.jogjakota.go.id (Gambar 1). Kelima rute/jalur sepeda ini juga dihimbau melalui Surat Edaran Walikota Yogyakarta No. 556/16320/SE/2020 untuk dikembangkan dalam hal pemasaran dan pemaketannya dengan kerjasama hotel-hotel, khususnya hotel bintang $3-5$ di Kota
Yogyakarta.

Pandemi COVID-19 yang terjadi sejak awal tahun 2020 juga berdampak besar dalam penurunan aktivitas ekonomi secara global, khususnya pada sektor pariwisata dan agen/biro perjalanan [4]. Pembatasan kegiatan dan mobilitas masyarakat, serta pembatasan akses antar wilayah juga membuat beberapa aktivitas pada sektor pariwisata terpaksa berhenti beroperasi. Kondisi seperti ini terjadi hampir di seluruh wilayah Indonesia, termasuk di Kota Yogyakarta. Berdasarkan data yang dirilis oleh Dinas Pariwisata Kota Yogyakarta [5], terjadi penurunan jumlah kunjungan yang cukup tajam pada pertengahan tahun 2020 atau bulan April s.d. Mei 2020. Oleh karena itu, programprogram promosi, khususnya di era new normal perlu dikembangkan untuk mendukung pemasaran dan pergerakan aktivitas pariwisata. Salah satu program promosi rutin yang diselenggarakan secara kolaboratif oleh Dinas Pariwisata Kota Yogyakarta dengan asosiasi dan industri pariwisata adalah Jogjavaganza. Berdasarkan rilis berita oleh Pemerintah Kota Yogyakarta [6], kegiatan Gowes Van Jogja menjadi salah satu agenda dalam rangkaian kegiatan Jogjavaganza pada tahun 2021 yang bertujuan untuk mengeksplorasi berbagai potensi lokal di kampung wisata.

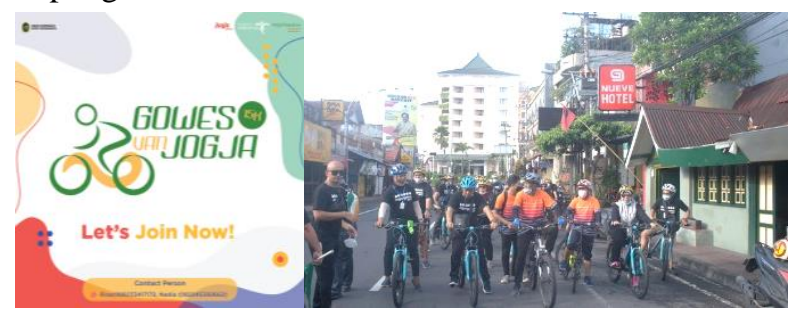

Gambar 2. Poster dan kegiatan luring (offline) Gowes Van Jogja 2021 Sumber Gambar : Dinpar Kota Yogyakarta \& tim survey UKDW

Kegiatan Gowes Van Jogja tahun 2021 terdiri dari dua bentuk, yakni bentuk virtual (online) dan bentuk kegiatan luring (offline) yang diadakan pada tanggal 25 Maret 2021. Bentuk kegiatan virtual (online) dilakukan dengan bentuk laporan kegiatan bersepeda dan kompetisi foto/video melalui instagram. Sedangkan kegiatan Gowes Van Jogja dalam bentuk luring (offline) diadakan secara terorganisir bagi para peserta Jogjavaganza yang merupakan pengelola usaha jasa di bidang biro perjalanan dan pariwisata. Sebagai upaya promosi pariwisata Kota Yogyakarta, maka para peserta Jogjavaganza berasal dari berbagai daerah di Indonesia. Terdapat 4 rute sepeda dalam kegiatan Gowes Van Jogja yang masing-masing memiliki tujuan akhir ke kampung wisata, yakni kampung wisata Cokrodiningratan, Tahunan, Prenggan, dan Tamansari. Hal ini juga menjadi salah satu upaya promosi dan perkenalkan kampung wisata kepada para peserta Jogjavaganza. Dengan demikian, evaluasi dari kegiatan 'Gowes Van Jogja' bertujuan untuk melakukan kajian dan uji coba layanan rute sepeda dalam upaya integrasi dengan kampung wisata Kota Yogyakarta. 
Evaluasi kegiatan 'Gowes Van Jogja' yang dilakukan pada program ini hanya terbatas pada evaluasi pada bentuk kegiatan luring (offline).

\section{METODE PELAKSANAAN}

Evaluasi dari Gowes Van Jogja sebagai upaya promosi kampung wisata dilaksanakan pada saat dan pasca kegiatan berlangsung. Pelaksanaan dengan skema ini bertujuan untuk mencari data dan informasi yang sesuai dan terukur dalam rangka memberikan rekomendasi kepada para pengelola kampung wisata Kota Yogyakarta yang terlibat rangkaian kegiatan Gowes Van Jogja. Pelaksanaan kegiatan evaluasi ini terdiri dari 4 tahapan bagian, antara lain :

\section{A. Tahap I : Koordinasi}

Pelaksanaan kegiatan evaluasi kegiatan Gowes Van Jogja dimulai dengan koordinasi bersama panitia JogjaVaganza 2021. Salah satu tim dalam program evaluasi ini juga berperan sebagai panitia pelaksanaan Jogjavaganza 2021 sehingga koordinasi dapat berjalan dengan baik dan lancar. Koordinasi dalam pelaksanaan survey dan wawancara dalam program Gowes Van Jogja dilaksanakan pada saat kegiatan berlangsung, yakni mulai pukul 06.00 hingga pukul 10.00 WIB. Tercatat sebanyak 98 peserta Gowes Van Jogja yang terbagi menjadi 4 rombongan sesuai dengan lokasi hotel tempat menginap peserta. Hal ini juga bertujuan untuk mempermudah koordinasi pada saat pelaksanaan program Gowes Van Jogja.

\section{B. Tahap II : Evaluasi}

Pelaksanaan evaluasi Gowes Van Jogja menggunakan metode observasi, wawancara, dan survey secara daring (online) dengan memanfaatkan Google Form sebagai media pengisiian bagi responden. Evaluasi dalam survey online ini menggunakan metode penilaian dengan skala likert dan pertanyaan yang bersifat terbuka (open-ended). Skala likert merupakan salah satu instrumen penelitian yang memiliki tujuan untuk mengukur pendapat seseorang terhadap suatu kejadian [7]. Setiap bagian pada instrumen evaluasi dalam skala likert juga bersifat bipolar yang memiliki gradasi jawaban, mulai dari nilai yang sangat positif hingga nilai yang sangat negatif. Selain itu, data evaluasi juga diperkaya dengan pertanyaan yang bersifat terbuka untuk mengakomodir saran dan masukan terkait pelaksanaan Gowes Van Jogja. Berikut merupakan daftar pertanyaan evaluasi yang digunakan:

TABEL I

DAFTAR PERTANYAAN EVALUASI GOWES VAN JOGJA 2021

\begin{tabular}{|l|l|}
\hline Aspek Evaluasi & Skala Likert \\
\cline { 1 - 1 } Layanan Kampung Wisata & - Sangat Tidak Baik \\
\cline { 1 - 1 } Rute/Jalur Sepeda & - Tidak Baik \\
\cline { 1 - 1 } Suasana Kampung Wisata & - Cukup Baik \\
\cline { 1 - 1 } Kerajinan Lokal & - Baik \\
\cline { 1 - 1 } Kuliner di Kampung Wisata & - Sangat Baik \\
\hline
\end{tabular}

Pertanyaan Terbuka (open-ended)

Saran/Masukan untuk Gowes Van Jogja \& Kampung Wisata?

Sumber : dokumentasi tim

\section{Tahap III : Diseminasi}

Setelah mendapatkan hasil evaluasi kegiatan Gowes Van Jogja melalui proses observasi, wawancara, dan survey secara daring (online). Tahap selanjutnya adalah melakukan analisis dan menyampaikan hasil kepada para pemangku kepentingan (stakeholders), khususnya pengelola kampung wisata. Pengertian diseminasi menurut Kementerian Pendidikan dan Kebudayaan [8] merupakan proses penyebarluasan gagasan atau ide. Tahap diseminasi dalam evaluasi ini mendapat kesempatan untuk difasilitasi oleh Dinas Pariwisata Kota Yogyakarta melalui kegiatan workshop pengembangan objek dan daya tarik wisata. Diseminasi ini juga bertujuan untuk mendengarkan masukan dari pengelola kampung wisata dan asosiasi pariwisata yang terkait inovasi wisata sepeda di Kota Yogyakarta. Workshop ini juga merupakan kegiatan untuk memperkenalkan dan membentuk koordinasi dari penerapan konsep Monalisa sebagai bentuk inovasi wisata bersepeda (cycling tourism) di Kota Yogyakarta.

\section{Tahap IV : Rekomendasi}

Pada tahap akhir dari program evaluasi dari kegiatan Gowes Van Jogja adalah penyusunan rekomendasi kepada para pemangku kepentingan (stakeholders) khususnya dalam pengembangan rute sepeda dan layanan wisata sepeda di kampung wisata Kota Yogyakarta. Rekomendasi ini juga menjadi luaran program evaluasi yang diharapkan dapat bermanfaat dalam menentukan dan merancang kegiatan-kegiatan promosi pariwisata Kota Yogyakarta, terutama yang berkaitan dengan program promosi wisata sepeda dan kampung wisata.

\section{HASIL DAN PEMBAHASAN}

Gowes Van Jogja merupakan salah satu program promosi pariwisata dalam rangkaian kegiatan JogjaVaganza 2021. Terdapat 68 dari 98 peserta Gowes Van Jogja yang menjadi responden dalam evaluasi ini. Di bawah ini merupakan sebaran responden ke dalam rute sepeda dan kampung wisata yang dikunjungi :

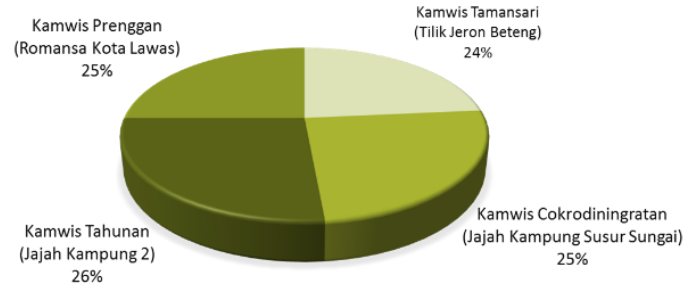

Gambar 3. Persentase Reponden dalam Evaluasi Gowes Van Jogja 2021 Sumber Gambar : tim survey UKDW 
Berdasarkan diagram di atas, persentase dan sebaran responden peserta Gowes Van Jogja cukup mewakili hasuil evaluasi kegiatan secara keseluruhan pada keempat rute maupun kampung wisata. Berikut ini merupakan hasil dan pembahasan yang telah disusun :

\section{A. Koordinasi Pelaksanaan}

Koordinasi pelaksanaan evaluasi 'Gowes Van Jogja' dilakukan bersamaan dengan rapat kegiatan JogjaVaganza 2021. Berdasarkan hasil koordinasi, maka ada terdapat 4 yang digunakan untuk kegiatan Gowes Van Jogja, antara lain Romansa Kota Lawas, Tilik Jeron Beteng, Jajah Kampung Susur Sungai, dan Jajah Kampung 2. Meskipun mengacu pada rute sepeda di website gowes.jogjakota.go.id, namun keempat rute sepeda yang digunakan dalam kegiatan Gowes Van Jogja mengalami sedikit modifikasi oleh panitia Jogjavaganza untuk mempermudah pelaksanaan dalam rangka kegiatan para peserta. Namun hal ini tidak merubah dari tujuan awal, yakni untuk memperkenalkan rute dan kampung wisata. Salah satu poin modifikasi adalah titik mulai (start point) yang berara di masing-masing lokasi hotel tempat peserta kegiatan menginap. Berikut merupakan rute sepeda dalam kegiatan Gowes Van Jogja 2021 :

\section{TABEL II}

RUTE SEPEDA KEGIATAN GOWES VAN JOGJA 2021

\begin{tabular}{|c|c|}
\hline Nama & Rute Sepeda \\
\hline $\begin{array}{l}\text { Romansa } \\
\text { Kota } \\
\text { Lawas } \\
\text { (Modifikasi) }\end{array}$ & $\begin{array}{l}\text { D’senopati Hotel - J1 Brigjen Katamso - Jl Kolonel } \\
\text { Sugiyono - J1 Menteri Supeno - Jl Veteran - Jl Ki Penjawi } \\
\text { - J1 Nyi Widi Adisoro - J1 Pangeran Romo - Jl. Karang } \\
\text { (Lap. Karang) - Jl. Raden Ronggo II - Jl. Kampung (Balai } \\
\text { Prenggan) - J1. Masjid Mataram - Jl. Lingkungan (Masjid } \\
\text { Mataram) - Jl. Masjid Besar - Jl. Singosaren - J1. } \\
\text { Kampung Singosaren - Gg. Soka - J1. Tegal Gendu - J1. } \\
\text { Inspeksi Kali Gajah Wong - Bendungan Lepen } \\
\text { (Kampung Wisata Prenggan) }\end{array}$ \\
\hline $\begin{array}{l}\text { Tilik Jeron } \\
\text { Beteng } \\
\text { (Modifikasi) }\end{array}$ & $\begin{array}{l}\text { Ruba Graha - Jl Mangkuyudan - J1 Parangtritis - J1 } \\
\text { Prawirotaman - J1 Sisingamangaraja - J1 Kolonel } \\
\text { Sugiyono - Museum Perjuangan. - J1 Kolonel Sugiyono - } \\
\text { J1 Brigjen Katamso - J1 Bu Ruswo - J1 Alun -Alun Utara } \\
\text { - Jl Kauman - J1 Ngasem - J1 Kadipaten Lor - J1 Nagan } \\
\text { Kulon - J1 Nagan Kidul - J1 Patehan Kidul - J1 } \\
\text { Langenarjan Kidul - J1 Gamelan - Jl. Siliran Lor - J1. } \\
\text { Madyosuro - Jl. Namburan Lor - Jl. Gamelan - J1. } \\
\text { Ksatriyan - Magangan - J1 Polowijan - Plaza Ngasem } \\
\text { (Kampung Wisata Tamansari) }\end{array}$ \\
\hline $\begin{array}{l}\text { Jajah } \\
\text { Kampung } \\
\text { Susur } \\
\text { Sungai } \\
\text { (Modifikasi) }\end{array}$ & $\begin{array}{l}\text { Hotel Horaios - J1 Margo Utomo - Jl Abu Bakar Ali - J1 } \\
\text { Ahmad Jajuli - Jl. Sudirman (Mc D) - J1. Gondolayu } \\
\text { (Cokrokusuman) - J1. Prof. Dr. Sardjito - Taman Robin - } \\
\text { Jl. Inspeksi Kali Code (Ke Utara) - J1. Mangkubumi - J1. } \\
\text { Gotong Royong I - J1. Kampung (Karangwaru - } \\
\text { Karangwaru Riverside - J1. Kampung (Karangwaru) - J1. } \\
\text { Magelang - J1. Jatimulyo - Jl. Jatimulyo } 4 \text { - Becak Maju } \\
\text { - Jl. Kampung (Bener) - J1. Bener - Jl. Manunggal - J1. } \\
\text { Kyai Mojo - J1. Tompeyan - Jl. HOS Cokroaminoto - } \\
\text { Museum Pangeran Diponegoro (Kampung Wisata } \\
\text { Cokrodiningratan) }\end{array}$ \\
\hline
\end{tabular}

\begin{tabular}{|l|l|}
\hline Jajah & Nueve Hotel - Jl Mataram - Jl Abu Bakar Ali - Jl Yos \\
Kampung & Sudarso - Jl Suroto - Jl Cik Ditiro - Jl. Kartini - Jl. Sagan \\
$\mathbf{2}$ & - Jl. Prof Yohanes - Jl. Kampung (Sagan) - Jl. Iromejan - \\
(Modifikasi) & Jl. Urip Sumoharjo - Gg. Randu - Embung Langensari - \\
& Jl. Langensari - Jl. Kemakmunan - Jl. Kusbini - Jl. \\
& Munggur - Jl. Mojo - Jl. Komp. B. Suprapto - Jl. Menur \\
& - Jl. Cempaka - Taman Bakung - Jl. Pengok Kidul - Jl. \\
& Teratai - Jl. Kampung - Jl. Gayam - Jl. Sukonandi - Jl. \\
& Kapas -Jl. Kusumanegara -Jl. Soga - Makam Wijaya \\
& Brata (Kampung Wisata Tahunan) \\
\hline
\end{tabular}

Sumber : Dinas Pariwisata Kota Yogyakarta

Selain itu, titik selesai (finish point) pada rute sepeda juga diarahkan pada kampung wisata yang terdapat pada masing-masing rute sepeda Monalisa. Hal ini juga mempermudah upaya panitia pelaksana dalam membawa kembali (loading out) sepeda yang dipakai oleh peserta Gowes Van Jogja. Setelah kegiatan tersebut, seluruh peserta akan kembali melanjutkan kegiatan city tour di Kota Yogyakarta dengan menggunakan bus pariwisata.

\section{B. Evaluasi Kegiatan}

Kegiatan Jogja Van Gowes dimulai pada pukul 07.00 WIB di masing-masing hotel tempat para peserta bermalam. Kegiatan bersepeda di pagi hari juga dapat meningkatkan kebugaran dan nyaman karena cuaca juga belum terlalu panas karena sinar matahari. Jalanan yang dilalui oleh para pesepeda juga belum terlalu ramai kendaraan bermotor, khususnya pada masa pandemi (new normal). Selain menggunakan alat keamanan bersepeda sesuai standar, para peserta dan panitia juga menerapkan protokol kesehatan yang ketat dalam mengikuti kegiatan Jogja Van Gowes. Berikut merupakan dokumentasi persiapan dan pelaksanaan kegiatan :

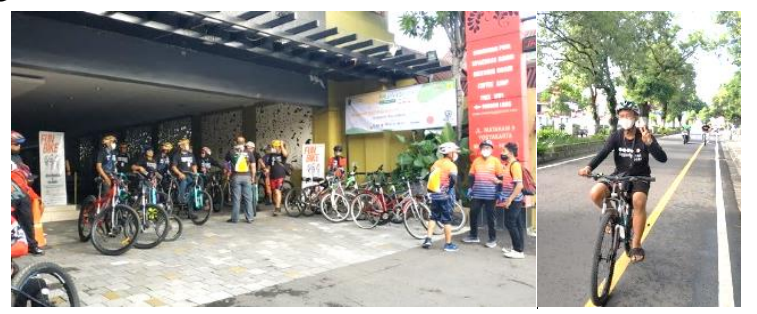

Gambar 4. Kegiatan Gowes Van Jogja 2021 di rute Jajah Kampung 2 Sumber: Dokumentasi Tim UKDW

Sebagai pengenalan dan promosi wisata sepeda, peserta Gowes Van Jogja juga melalui rute sepeda yang menawarkan beragam daya tarik wisata di Kota Yogyakarta, khususnya bangunan cagar budaya, obyek wisata, Ruang Terbuka Hijau (RTH), hingga kampung wisata. Beberapa ruas jalan di Kota Yogyakarta juga telah dilengkapi dengan jalur sepeda (bike lane) dengan ditandai marka garis berwarna kuning. Jalur sepeda menurut dokumen Perancangan Fasilitas Pesepeda Kementerian Pekerjaan Umum dan Perumahan Rakyat [9] merupakan jalur khusus yang didesain untuk memisahkan pesepeda 
dengan kendaraan bermotor dengan lebar jalur yang disarankan adalah 1,74 meter untuk satu lajur sepeda.

Pada titik akhir pemberhentian akhir masing-masing rute sepeda, para peserta Gowes Van Jogja menikmati sambutan dan penjelasan dari pengelola kampung wisata. Peserta juga diberikan pengenalan tentang profil, produk/layanan, dan berbagai potensi lokal yang terdapat pada kampung wisata. Para peserta yang mayoritas adalah penyedia jasa perjalanan wisata dari berbagai daerah juga turut bertanya seputar potensi wisata dan kerjasama. Selain itu, Usaha Kecil da Menengah (UKM) atau kelompok usaha lokal yang terdapat di kampung wisata juga diperkenalkan, khususnya di bidang kuliner dan kerajinan. Kegiatan ini juga dilakukan sebagai upaya promosi bagi potensi lokal kampung wisata Kota Yogyakarta. Setelah menikmati suasana, sajian kuliner, dan perkenalan di kampung wisata Kota Yogyakarta, para peserta selanjutnya melanjutkan perjalanan untuk kembali mengikuti kegiatan JogjaVaganza 2021.

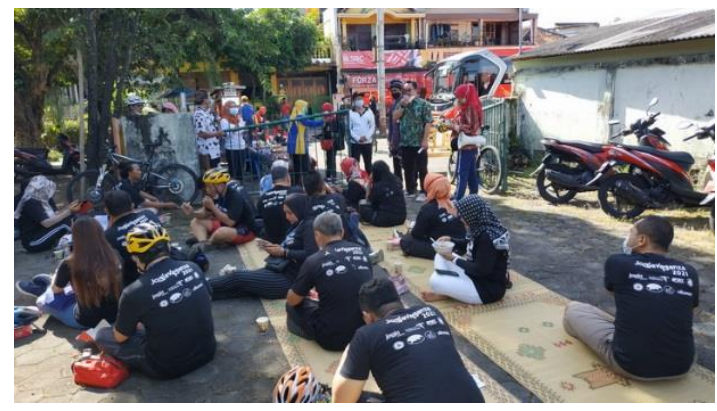

Gambar 5. Kunjungan Peserta ke Kampung Wisata Tahunan Sumber: Dokumentasi Tim UKDW

Secara umum, kegiatan Gowes Van Jogja berjalan dengan baik dan lancar sesuai dengan rencana panitia. Para peserta juga mendapatkan wawasan dan jejaring dengan kampung wisata Kota Yogyakarta. Berdasarkan hasil evaluasi dari penilaian responden, terdapat 64 dari total 98 peserta yang mengisi kuisioner secara daring (online). Hasil penilaian peserta terhadap kegiatan Gowes Van Jogja menunjukan indeks kepuasan sebesar 80,9 dari skala 0-100 yang dapat masuk dalam kategori 'sangat baik' atau dalam skala 80-100. Berikut ini merupakan hasil penilaian responden dengan menggunakan skala likert dalam tingkat kepuasan :

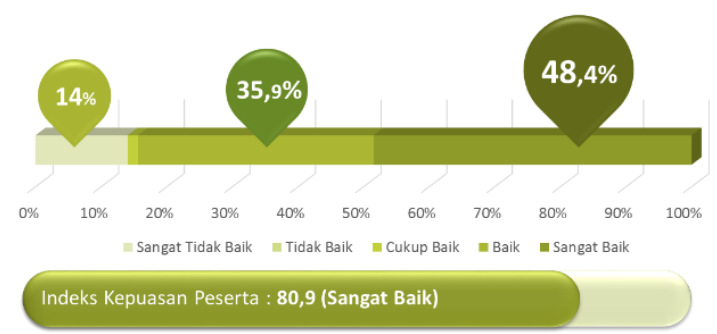

Gambar 6. Hasil Evaluasi Kepuasan Peserta Gowes Van Jogja 2021

\section{Sumber: Dokumentasi Tim UKDW}

Kegiatan Gowes Van Jogja juga menerapkan protokol kesehatan yang ketat sehingga para peserta dan pengelola kampung wisata tidak menemui kendala dalam pelaksanaan. Berikutnya dalam penilaian evaluasi peserta kegiatan Gowes Van Jogja secara lebih detail dilakukan pada beberapa aspek yang menjadi perhatian bagi peserta, antara lain aspek layanan kampung wisata, rute sepeda, suasana kampung wisata, kerajinan lokal, dan kuliner yang terdapat di masing-masing kampung wisata. Kelima aspek ini juga merupakan aspek yang diperkenalkan kepada para peserta Gowes Van Jogja. Berikut ini merupakan hasil dari kuisioner penilaian yang diisi secara daring (online) :

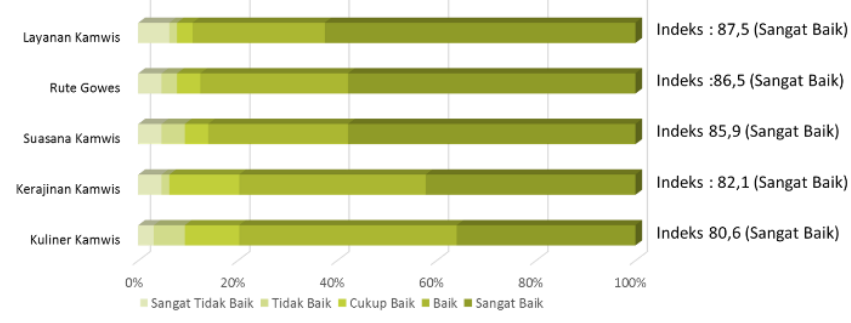

Gambar 7. Hasil Evaluasi Aspek Promosi dalam Gowes Van Jogja 2021 Sumber: Dokumentasi Tim UKDW

Hasil evaluasi pada gambar di atas menunjukan bahwa aspek layanan kampung wisata menjadi aspek yang paling unggul dengan indeks nilai sebesar 87,5 yang masuk dalam kategori 'sangat baik'. Indeks ini juga menunjukan bahwa kampung wisata telah memberikan layanan yang sangat baik kepada para peserta sebagai pengunjung atau wisatawan. Selain itu, rute sepeda juga menempati urutan kedua dengan indeks sebesar 86,5 dalam kategori 'sangat baik' yang menunjukan bahwa jalur sepeda telah sesuai dengan harapan pada peserta. Rute sepeda yang berorientasi pada modifikasi keempat jalur Monalisa juga menawarkan beberapa tempat pemberhentian yang menarik bagi para peserta gowes. Suasana kampung wisata juga mendapat penilaian dalam kategori 'sangat baik' dari peserta karena kegiatan Gowes Van Jogja telah menawarkan nuansa kampung yang nyaman, serta didukung oleh masyarakat sekitar yang ramah terhadap wisatawan.

Aspek kerajinan dan kuliner yang ditinjau oleh peserta berada pada urutan dua terbawah dalam penilaian evaluasi. Meskipun demikian, penilaian evaluasi pada kedua aspek tersebut tetap masuk dalam katergori 'sangat baik'. Kuliner dan kerajinan juga menjadi aspek yang mampu menggerakan ekonomi masyarakat lokal di kampung wisata. Terdapat beberapa saran yang dikumpulkan melalui wawancara, serta pertanyaan terbuka dalam kuisioner secara daring (online) yang menunjukan apresiasi dan dukungan terhadap pengelola kampung wisata untuk semakin meningkatkan kreativitas dalam paket layanan, seperti mengajak peserta untuk terlibat dalam proses 
memasak (cooking activity) untuk kuliner lokal. Selain itu, terdapat masukan dalam jadwal kegiatan Gowes Van Jogja untuk berangkat atau mulai lebih pagi agar dapat menikmati sarapan di kampung wisata. Karena durasi waktu kunjungan di kampung wisata yang relatif pendek dalam rangkaian kegiatan Jogjavaganza, para peserta juga tidak sempat untuk mengeksplorasi lebih banyak lagi tentang kerajinan dan kuliner lokal yang terdapat di masing-masing kampung wisata.

\section{Diseminasi Hasil}

Kegiatan diseminasi atau penyebarluasan gagasan dari hasil evaluasi dilakukan dalam acara workshop objek daya tarik wisata sepeda yang diselenggarakan langsung oleh Dinas Pariwisata Kota Yogyakarta pada hari Senin, tanggal 12 April 2021. Para peserta workshop adalah para pemangku kepentingan (stakeholders) yang terlibat pengembangan program produk/layanan wisata sepeda di Kota Yogyakarta, khususnya pengelola kampung wisata. Adapun tema yang diangkat oleh Dinas Pariwisata Kota Yogyakarta [10] pada workshop ini adalah 'Wisata Sepeda sebagai Inovasi Sport Tourism dan Strategi Meningkatkan Daya Tarik Pariwista Jogja di Era Pandemi'. Kegiatan workshop yang dipimpin langsung oleh Kepala Dinas Pariwisata Kota Yogyakarta bertujuan untuk membangun branding program Monalisa, serta menginisiasi adanya kolaborasi antara stakeholders dalam pengelolaan wisata sepeda di Kota Yogyakarta. Inovasi wisata sepeda ini diharapkan mampu menggerakan kembali aktivitas pariwisata yang sempat redup karena dampak pandemi COVID-19. Berdasarkan paparan hasil evaluasi yang disampaikan, peserta workshop memberikan pendapat terkait dengan pengembangan jalur sepeda Monalisa yang lebih banyak melewati kampung-kampung wisata agar semakin menjadi bentuk promosi, serta semakin membuka peluang dan potensi ekonomi.

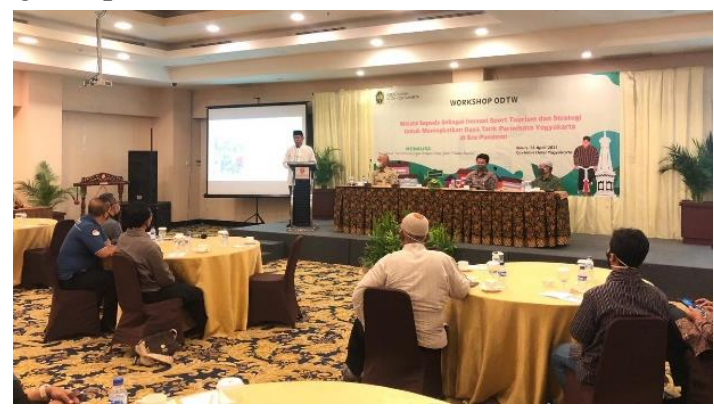

Gambar 8. Kegiatan Diseminasi dalam Workshop Dinpar Kota Yogyakarta

Sumber: Dokumentasi Tim UKDW

Selain diseminasi hasil evaluasi 'Gowes Van Jogja' dan diskusi pengembangan wisata sepeda dari unsur akademisi, workshop ini juga menghadirkan narasumber dari unsur pemerintah daerah, antara lain Walikota Yogyakarta,
Kepala Dinas Pariwisata DIY, dan Wakil Ketua I DPRD Kota Yogyakarta. Berdasarkan paparan materi para narasumber, pengembangan inovasi wisata sepeda di Kota Yogyakarta melalui program kolaborasi pada jalur Monalisa merupakan salah satu upaya untuk menghidupkan aktivitas pariwisata, termasuk bagi objek dan kampung wisata yang dilewati oleh rute sepeda ini. Wisata sepeda juga terus didukung oleh pemerintah daerah, salah satunya dengan perawatan dan pengembangan infrastruktur pendukung bagi para pesepeda, seperti perawatan jalan, pengadaan fasilitas untuk penanda (signage) jalur sepeda dan pembehentian (pit stop) bagi para pesepeda, serta berbagai fasilitas pendukung lainnya. Kota Yogyakarta juga memiliki banyak titik pemberhentian yang menarik bagi wisatawan untuk dapat berfoto dan menikmati suasana kota. Adanya komunitas sepeda dan acara (event) sepeda di Kota Yogyakarta juga menjadi peluang dan daya tarik dalam pengembangan inovasi pariwisata daerah.

\section{Rekomendasi}

Berdasarkan hasil penilaian evaluasi dan diseminasi terkait program promosi Gowes Van Jogja, terdapat beberapa rekomendasi sebagai luaran program Pengabdian kepada Masyarakat, antara lain :

\section{1) Pengembangan Program Promosi Gowes Van Jogja}

Program promosi dalam kegiatan Gowes Van Jogja yang diselenggarakan oleh Dinas Pariwisata Kota Yogyakarta perlu dikembangkan dan dipadukan dengan beberapa event lainnya, khususnya yang terkait dengan promosi pariwisata Kota Yogyakarta. Fenomena bersepeda sebagai gaya hidup sehat masyarakat di era new normal perlu ditangkap sebagai peluang untuk menggerakan kembali aktivitas pariwisata. Inisiasi untuk membentuk citra (branding) Kota Yogyakarta sebagai kota sepeda juga semakin kuat ketika program promosi Gowes Van Jogja dilaksanakan secara rutin pada setiap kesempatan promosi pariwisata. Kegiatan Gowes Van Jogja dapat menjadi upaya untuk memperkenalkan berbagai objek daya tarik wisata, termasuk kampung-kampung wisata melalui kegiatan bersepeda di Kota Yogyakarta.

\section{2) Pemaketan Layanan Kampung Wisata dengan Monalisa}

Pemaketan produk/layanan kampung wisata dengan rute sepeda Monalisa dapat menjadi salah satu bentuk kolaborasi dan upaya inovasi pengembangan wisata sepeda di Kota Yogyakarta. Konsep kegiatan promosi Gowes Van Jogja yang memperkenalkan kampung wisata pada titik akhir pemberhentian (finish) rute sepeda merupakan gagasan yang strategis, serta dapat dikembangkan melalui berbagai paket wisata yang menarik bagi wisatawan. Selain layanan untuk memperkenalkan profil dan potensi kampung wisata bagi para pesepeda, bidang usaha kuliner dapat menjadi salah satu jenis paket yang akan dibutuhkan olehs 
wisatawan. Kegiatan pelatihan (workshop) terkait kegiatan seni budaya lokal, hingga pelatihan pembuatan aneka kerajinan lokal juga berpotensi untuk masuk dalam paket layanan wisata sepeda yang dapat dikelola oleh kampung wisata.

\section{3) Pengembangan Rute Sepeda dan Pendukung Promosi}

Rute sepeda yang digunakan dalam kegiatan Gowes Van Jogja telah berupaya untuk memperkenalkan berbagai objek daya tarik wisata di Kota Yogyakarta, khususnya kampung wisata. Sebagai rekomendasi pengembangan berikutnya, rute sepeda dapat melewati titik-titik potensi lokal yang menjadi keunggulan kampung wisata. Upaya modifikasi rute sepeda Monalisa yang dilakukan oleh Dinas Pariwisata Kota Yogyakarta merupakan langkah strategis guna menyesuaikan efisiensi promosi kampung wisata dengan kemudahan dalam pelaksanaan kegiatan JogjaVaganza 2021. Selain itu, material pendukung promosi kepada wisatawan/pesepeda yang berkunjung ke kampung wisata juga perlu ditingkatkan, seperti informasi profil kampung, paket wisata, dan potensi lokal kampung wisata yang dapat disajikan secara digital, maupun dalam bentuk cetak.

\section{KESIMPULAN}

Kegiatan Gowes Van Jogja sebagai bentuk promosi pariwisata Kota Yogyakarta merupakan langkah strategis dalam memperkenalkan rute sepeda Monalisa, serta potensi lokal di kampung wisata. Dari hasil evaluasi terhadap upaya promosi pariwisata Kota Yogyakarta melalui kegiatan Gowes Van Jogja dapat disimpulkan telah terlaksana dengan sangat baik, termasuk dalam beberapa aspek yang meliputi rute sepeda, layanan wisata, suasana kampung, kuliner, dan kerajinan lokal. Gowes Van Jogja bahkan dapat menjadi pematik untuk kegiatan promosi wisata sepeda di kampung-kampung wisata lainnya di Kota Yogyakarta. Selain itu, keberhasilan dalam penyelenggaraan kegiatan Gowes Van Jogja juga tidak terlepas dari kerjasama antar pihak, baik dari pemerintah, asosiasi industri pariwisata, hingga kampung wisata yang tergabung dalam kepanitiaan. Dengan demikian, dapat disimpulkan pula bahwa kegiatan Gowes Van Jogja memiliki potensi untuk dilanjutkan dan diterapkan pada agenda promosi pariwisata Kota Yogyakarta untuk semakin memperkenalkan rute sepeda Monalisa dan kampung wisata.

\section{UCAPAN TERIMA KASIH}

Terima kasih kami ditujukan kepada UKDW, Dinas Pariwisata Kota Yogyakarta, BP2KY, dan Forkom Kampung Wisata di Kota Yogyakarta, beserta pada peserta dan panitia kegiatan Jogjavaganza 2021 yang telah mendukung dalam pelaksanaan program evaluasi ini. Terima kasih pula kepada segenap Bpk/Ibu, dan temanteman tim survey dalam kajian kegiatan Gowes Jogja.

\section{DAFTAR PUSTAKA}

[1] Nurrahmah, K., Safitri, R., Sumiati, Fitriani, P. (2021). Tren Keluarga Bersepeda di Era New Normal. Az-Zahra: Journal of Gender and Family Studies. Vol. 1 No. 2, pp. 106-118, 2021. Available:

https://journal.uinsgd.ac.id/index.php/azzahra/article/view/11671

[2] Thorik, M. J. (2015). Aksi Kolektif Dalam Bersepeda: Studi Banding Atas Sego Segawe (Sepeda Kanggo Sekolah lan Nyambut Gawe) dan JLFR (Jogja Last Friday Ride) di Kota Yogyakarta. Jurnal Sosiologi Reflektif, Vol. 9, No. 2, pp. 247-272, 2015. Available: http://ejournal.uinsuka.ac.id/isoshum/sosiologireflektif/article/view/ 1122

[3] Wirawan, K. (2016). Wisata Sepeda dalam Mewujudkan Pariwisata Berkelanjutan di Sanur. Jurnal Master Pariwisata (JUMPA). Vol. 2 No. 2 pp. 247-272, 2016. Available: https://ojs.unud.ac.id/index.php/jumpa/ article/view/18343

[4] Berger, R. (2020). World Economic Growth Plunges Due To Coronavirus - Which Industries Are Suffering The Most. [Online]. Available:

https://www.rolandberger.com/en/Insights/Publications/Worldeconomic-growth-plunges-due-to-coronavirus-which-industriesare.html

[5] Dinas Pariwisata Kota Yogyakarta (2020). Perkembangan Kunjungan Wisatawan Nusantara Kota Yogyakarta Tahun 2020. [Online]. Available: https://pariwisata.jogjakota.go.id/

[6] Pemerintah Kota Yogyakarta (2021). Pemkot Yogya Promosi Pariwisata Lewat Jogjavaganza. [Online]. Available: https://warta.jogjakota.go.id/ detail/index/14410.

[7] Sugiyono, (2012). Metode Penelitian Kuantitatif Kualitatif dan $R \& D$. Bandung: Alfabeta

[8] BPPB, (2016). Kamus Besar Bahasa Indonesia (KBBI) Daring, Badan Pengembangan dan Pembinaan Bahasa. [Online]. Available: https://kbbi.kemdikbud.go.id/entri/diseminasi.

[9] Kementerian Pekerjaan Umum dan Perumahan Rakyat (2021) Pedoman Perancangan Fasilitas Pesepeda: Perancangan Fasilitas Pesepeda. Jakarta: Direktorat Jenderal Bina Marga, Kementerian Pekerjaan Umum dan Perumahan Rakyat. Available:https://binamarga.pu.go.id/uploads/ files/883/pedomanperancangan-fasilitas-pesepeda.pdf

[10] Dinas Pariwisata Kota Yogyakarta (2021). Workshop Wisata Sepeda Sebagai Inovasi Sport Tourism Yogyakarta di Era Pandemi. [Online]. Available: 
